\title{
Does External Environment Influence Organizational Performance? The Case of Kenyan State Corporations
}

\author{
Njoroge J. K. ${ }^{1}$, Ongeti W. J. ${ }^{2}$, Kinuu D. ${ }^{3, *} \&$ Kasomi, F. M. ${ }^{4}$ \\ ${ }^{1}$ Ministry of Energy \& Petroleum, Government of Kenya, Kenya \\ ${ }^{2}$ Strategic Management, Pan African Christian University, Nairobi, Kenya \\ ${ }^{3}$ Telecommunications Industry, Kenya \\ ${ }^{4}$ Ministry of Energy \& Petroleum, Government of Kenya, Kenya \\ *Correspondence: Telecommunications Industry, Kenya. E-mail: kinuudavid@gmail.com
}

Received: June 23, 2016

Accepted: June 30, 2016 Online Published: July 25, 2016

doi:10.5430/mos.v3n3p41

URL: http://dx.doi.org/10.5430/mos.v3n3p41

\begin{abstract}
External environment's direct influence on organizational performance has not attracted as much scholarly attention as the strategic management practice. The main objective of the study was to establish the influence of external environment on performance of Kenyan State corporations. The three dimensions of external environment namely munificence, complexity and dynamism were used to measure the variable while performance was measured along all the indicators of the sustainable balanced score card. The study's population consisted of 108 Kenyan state corporations and data was collected from 98 organizations. The results revealed that all the hypotheses were supported. It was established that external environment had a positive significant influence on all the indicators of performance. It was evident from the findings that the effect of external environment on organizational performance, while conventionally thought to be negative, the research showed otherwise. It is most likely that Kenya state corporations have ensured a proper environmental scanning that has led to an accurate stakeholders mapping. The stakeholders mapping has most likely led to favorability of relationships hence the positive effect of external environment. External environment ought not to impact organizational performance negatively. Results also reveal that indeed the external environment has a direct relationship and influence on organizational performance. Industrial organization economics theory suggested the structure-conduct-performance paradigm which was later matched with strategic management's the environment-strategy-performance. The results of this study seem to allude to an environment-performance paradigm. More scholarly poking is therefore necessary to determine the extent to which the direct relationship exists.
\end{abstract}

Keywords: external environment; state corporations; organizational performance

\section{Introduction}

The external environment is a firm's aggregate of factors, exogenous to the organization that may have potential to impact organizational performance (Murgor, 2014). All organizations are open systems, hence environment-serving Organizations (Ansoff \& Sullivan, 1993). The external environment provides firms with inputs which they transform to outputs through internal processes and then the outputs are given back to the environment. Organizations cannot single handedly have full control over occurrences on the environment. The environment is source of constraints, contingencies, problems as well as opportunities that affect the terms on which organizations transact business (Khandwalla, 1977; Bourgeois, 1980).

Regardless of the industry in which organizations compete, the external environment influences firms as they seek strategic competitiveness and the earning above average returns (Hitt, Ireland, Sirmon \& Trahms, 2011). According to Welch and Welch (2005), an overall assessment of the conditions that affect firms today indicates that for most organizations, their external environment is filled with uncertainty. To successfully deal with this uncertainty and achieve strategic competitiveness in order to thrive, firms must be aware of and fully understand the different manifestations of the external environment. It is such understanding that organizations can take actions such as 
building capabilities and core competences that would help them in buffering themselves from any negative environmental effects while pursuing opportunities (Kacperczyk, 2009).

Concerns on what should be observed and measured in the external environment remains unresolved (Machuki \& Aosa, 2011), because it is impossible to examine everything occurring and some elements could be more relevant to some organizations than others (Murgor, 2014). Machuki and Aosa (2011) suggest that the environmental construct should be treated as consisting two broad aspects, the factors (internal and external) and second the dimensions. Notably, the latter forms the basis for assessing the former. The external environment provides three dimensions of manifestation which are complexity, munificence and dynamism (Duncan, 1972a; Machuki \& Aosa, 2011).

\section{External Environment}

An environment is complex if it provides excessively diverse and or numerous dimensional units of information, which requires substantial integration of, thought and can be described as multidimensional (Miller, 1993). Environmental complexities are viewed as the interaction between environmental risks, dependency and inter firm relationships (Osborn \& Hunt, 1974). Environmental complexity is considered an important, if not most the most important variable in the environment surrounding the firm (Murgor, 2014). On the other hand, environmental munificence is the scarcity or abundance of critical resources by one or more firms operating within an environment (Castrogiovanni, 1991). Firms seek munificent environments and attempt to enhance the munificence of their present environments (Dess \& Beard, 1984).

Dynamism refers to the ever changing nature of the external environment (Dreyer \& Gronhaug, 2004). The ever changing nature of the external environment may transform the purpose of the firm and the environment in which it operates (McMahon \& Carr, 1999). Organizations may set targets, negotiate and agree on performance indicators for execution in order to achieve superior performance. Nevertheless, occurrences in the external environment may manifest themselves in a manner that accelerates or decelerates the relationship between strategy implementation and organizational performance.

Institutional theory postulate that the business environment in which organizations operates exerts pressure on them (Kinuu, 2014). The pressures from the environment provoke different responses as organizations seek legitimacy in order to survive and prosper in their environment (Scott, 2008). When innovative structures are developed and legitimized through the process of institutionalization, they serve to improve on operational efficiency and as such organizational performance. Institutional theory asserts that market pressures and institutionalized managerial practices are considered the most important factors that influence organizational performance (DiMaggio \& Powell, 1991). Managers as institutional actors are the causal agents that have the ability to interpret strategic stimulus and craft as well as implement strategic responses (Scott, 2008). Since the period immediately after disenchantment of strategy planning in the late 1970s, the role of the external environment can no longer be ignored in strategic management. Organizations can no longer predict with precision what they will be doing five years down the line. Occurrences within this environment may have a bearing on the organizational performance (Messah \& Kariuki, 2011; GoK, 2013). Environmental conditions such as uncertainty, dynamism, hostility, the number of relevant components in the environment and the interpersonal relationships between these components, all increase the perceived complexity in managing organizations (Lehner, 2004).

\section{Organizational Performance}

Organizational performance is a recurrent theme of great interest to both academic scholars and practicing managers (Venkatraman, \& Ramanujam, 1987). It is the most sought outcome and common denominator across organizations (Ongeti, 2014). March and Sutton (1997) opined that most studies in strategic management conceptualize performance as a dependent variable and seek to identify variables that explain variation in performance. It however, continues to be a contentious subject among organizational researchers in terms of definition and measurement (Chakravathy, 1986; Machuki \& Aosa, 2011) as various scholars and researchers define and conceptualize performance differently.

\section{External Environment and Performance}

Organizations face turbulent and rapid changing environments that are translated into complex, multifaceted and interlinked streams of initiatives. This turbulence affect work, organizational designs and resource allocation thus 
leading to variations in performance (Messah \& Kariuki, 2011). Delays in availability of resources, political interference and variations on the economic situations have been attributed to poor organizational performance (Kobia \& Mohamed, 2006) even with a perfectly formulated strategy. Organization theory proponents emphasize that organizations must adapt to their environment if they have to survive (Machuki \& Aosa, 2011). According to Bagire and Namada (2013) organizational outcomes are partially predicted by the environmental manifestations. Changes in the external environment may be favorable or unfavorable to organizational outcomes (Edmondson et al., 2003; Tacheva, 2007). Factors in the external environment influence organizational processes differently (Tacheva, 2007). Superior organization performance is realized when the responsiveness of an organization's strategy matches the turbulence in the environment (Ansoff \& Sullivan, 1993). The external environment remains a crucial aspect in the strategic management. Thus it can be postulated that the external environment has an influence on organizational performance.

\section{The Research Problem}

The relationship between external environment and performance has been studied previously. For instance, Tan and Litschert (1994) established that there increased environmental uncertainty is negatively related to proactive strategies and positively related to defensive strategies for higher performance. Additionally, firms without a clear cut generic strategy performed less well than those using generic strategies. Venkatraman and Prescott (1990) concluded that there was a positive performance impact of environment strategy co-alignment. Machuki and Aosa (2011) established that the external environment had an influence on performance of firms listed on the Nairobi securities exchange. It is evident from most of previous studies in strategic management that focus has been on the relationship between external environment and performance as intervened by strategy or strategic responses. Further, while theoretical and conceptual arguments posit that organizations are environmental serving and dependent (Ansoff and McDonell, 1992) conventional thinking and practice perceives external environment as an adversity to performance. Now than any time before, organizations are faced with more environmental dynamism, complexity and munificence. Could manifestations in the external environment be occurring so rapidly that performance is influenced before strategy interventions can be crafted and implemented?

Most Kenyan state corporations attribute any negative variations on set performance targets to external environmental challenges (Kobia and Mohamed, 2006; Mkalama 2014). However, positive performance is most likely attributed to managerial ingenuity. Further, there exists a gap on the influence of external environment on all the contemporary indicators of measuring performance. These are financial, customer focus, social responsiveness, environmental focus, internal business processes, learning and growth. Does external environment directly influence performance of Kenyan state corporations?

This study was an attempt to establish the effect of external environment on organizational performance of Kenyan state owned corporations using the hypotheses

$\mathbf{H}_{\mathbf{1}}$ : External environment has a significant influence on organizational performance of Kenyan state corporations;

$\mathbf{H}_{\mathbf{1} \mathbf{a}}$ : External environment has a significant influence on financial performance of Kenyan state corporations;

$\mathbf{H}_{\mathbf{1 b}}$ : External environment has a significant influence on customer focus performance of Kenyan state corporations;

$\mathbf{H}_{1 \mathbf{c}}$ : External environment has a significant influence on internal business processes of Kenyan state corporations;

$\mathbf{H}_{\mathbf{1 d}}$ : External environment has a significant influence on learning and growth of Kenyan state corporations;

$\mathbf{H}_{1 \mathbf{1}}$ : External environment has a significant influence on social equity of Kenyan state corporations;

$\mathbf{H}_{1 \mathbf{f}}$ : External environment has a significant influence on environmental performance of Kenyan state corporations;

\section{Methodology}

The positivistic research philosophy was employed by this study. This was because of the need to remain objective, test theories and move from the known to the unknown. Similar studies by Ombaka and Machuki (2015), Murgor (2014) and Njoroge et al., (2015) had successfully used this philosophy. The study adopted a descriptive 
cross-sectional survey so as to carry out once and represent a snapshot of a point in time. Cross-sectional surveys enable collection of data across a large number of organizations at one point in time (Cooper \& Schindler, 2006). This study focused on 108 Kenyan state corporations.

Primary data was collected using a semi-structured questionnaire. The questionnaire comprised of closed ended questions and a few open ended ones, guided by conceptual and empirical literature. The research instrument was administered through drop and pick method by the researcher assisted by three research assistants as well as email. This method was successfully used by Mkalama (2014) and Ongeti (2014) in the same context. All the 108 corporations were approached and served with the questionnaire out of which 95 filled and returned resulting into a response rate of 88 percent. This rate compares well with previous studies in the Kenyan state corporations. Awino and Mutua (2014) had a response rate of 77 percent; Ongeti (2014) had 65 percent while Mkalama (2014) had 82 percent.

\section{Data Analysis and Results}

Once data had been collected, it was prepared, organized, analyzed, and used to report the findings. Data preparation included questionnaire checking, sorting, editing, coding and data cleaning. Linear regression was used to establish the influence of strategy implementation on performance.

The study's preliminary findings included descriptive statistics of the variables. Measures of central tendency, dispersion, one sample t-test coefficient of variation and correlation analysis were included in the preliminary findings. External environment was the independent variable of the study. The external environment is all those aspects beyond any single organization's control. To operationalize the external environment, the study focused on the dimensions of the external environment. These dimensions are dynamism, complexity and munificence. The results of the descriptive statistics for external environment are as shown in Table 1.

Table 1. Descriptive Statistics for External Environment

\begin{tabular}{lcccccc}
\hline Description & N & Mean & $\begin{array}{c}\text { Std. } \\
\text { Deviation }\end{array}$ & t-value & Sig. (2 tailed) & CV (\%) \\
\hline Dynamism & 95 & 3.9182 & .39332 & 97.096 & 0.000 & 10 \\
Complexity & 95 & 3.7251 & .31656 & 114.693 & 0.000 & 8 \\
Munificence & 95 & 3.7142 & .31090 & 116.442 & 0.000 & 8 \\
\hline
\end{tabular}

Source: Fieldwork (2015)

Table 1 shows that the three constructs of dynamism, complexity and munificence had a mean score of above the mean of 2.5. Dynamism had the highest mean score of 3.9182 implying that the external environment of most organizations had largely changed over the last five years. Complexity and munificence had mean scores of 3.7251 and 3.7142, respectively. It is clear that the external environment of most organizations have largely been complex and unfavorable for the last 5 years. Further, variations in the responses were low (CVs ranging from 8 for complexity and munificence to 10 dynamism percent) implying that respondents generally agreed on the statements regarding related to process.

A correlation analysis was conducted to establish the relationship among the three constructs of the external environment. The results are presented in Table 2.

Table 2. Correlation Analysis of External Environment

\begin{tabular}{|c|c|c|c|c|}
\hline Description & & Munificence & Dynamism & Complexity \\
\hline Munificence & $\begin{array}{l}\text { Pearson Correlation } \\
\text { Sig. (2-tailed) }\end{array}$ & 1 & & \\
\hline Dynamism & $\begin{array}{l}\text { Pearson Correlation } \\
\text { Sig. (2-tailed) }\end{array}$ & $\begin{array}{l}.684^{* *} \\
.000\end{array}$ & 1 & \\
\hline Complexity & $\begin{array}{l}\text { Pearson Correlation } \\
\text { Sig. (2-tailed) }\end{array}$ & $\begin{array}{l}.965^{* *} \\
.000\end{array}$ & $\begin{array}{l}.687^{* *} \\
.000\end{array}$ & 1 \\
\hline
\end{tabular}

Source: Fieldwork (2015) 
The results of the correlation analysis are as shown in Table 4.2. Notably, all the three variables were strongly and positively correlated with each other. The relationships were equally all statistically significant. Remarkably, complexity had the strongest positive relationship $(\mathrm{R}=0.965)$ with munificence suggesting that the more complex the external environment was the more favorable it became for Kenyan state corporation to operate.

To test the manifestation of the three dimensions of the external environment, the respondents were asked to indicate on a 5-point Likert scale the extent to which each dimension had manifested itself in the organization. Table 3 presents the results of one-sample $t$-test statistics carried out.

Table 3. Descriptive Statistics for External Environment Statements

\begin{tabular}{|c|c|c|c|c|c|c|}
\hline Statements & $\mathbf{N}$ & Mean & Std. Deviation & $\mathbf{C V}$ & $\mathbf{t}$ & Sig. (2-tailed) \\
\hline \multicolumn{7}{|c|}{$\begin{array}{l}\text { Munificence (The extent to which developments in each of the factors have been favorable to the firm during } \\
\text { the last five years ) }\end{array}$} \\
\hline Political factors & 95 & 4.41 & .676 & 15 & 63.567 & .000 \\
\hline Economic factors & 95 & 2.91 & .787 & 27 & 36.004 & .000 \\
\hline Technological factors & 95 & 3.21 & 1.100 & 34 & 28.441 & .000 \\
\hline Socio-Cultural factors & 95 & 2.87 & .775 & 27 & 36.133 & .000 \\
\hline Regulatory factors & 95 & 3.22 & 1.122 & 35 & 27.979 & .000 \\
\hline Ecological factors & 95 & 4.14 & .752 & 18 & 53.586 & .000 \\
\hline Your Creditor’s actions & 95 & 4.06 & 1.019 & 25 & 38.861 & .000 \\
\hline Market factors (customer behavior) & 95 & 4.51 & .698 & 15 & 62.945 & .000 \\
\hline Labour market dynamics & 95 & 3.11 & .973 & 31 & 31.114 & .000 \\
\hline Trade unions’ activities & 95 & 3.32 & 1.169 & 35 & 27.639 & .000 \\
\hline $\begin{array}{l}\text { Threat of new entrants into your } \\
\text { corporation's industry }\end{array}$ & 95 & 4.11 & .751 & 18 & 53.314 & .000 \\
\hline $\begin{array}{l}\text { Bargaining power of suppliers over your } \\
\text { organization }\end{array}$ & 95 & 4.02 & 1.021 & 25 & 38.392 & .000 \\
\hline $\begin{array}{l}\text { Bargaining power of the public at large } \\
\text { over your organization }\end{array}$ & 95 & 4.39 & .762 & 17 & 56.141 & .000 \\
\hline \multicolumn{7}{|c|}{ Dynamism (The extent to which the following factors have changed in the last five years) } \\
\hline Political factors & 95 & 3.20 & 1.117 & 35 & 27.933 & .000 \\
\hline Economic factors & 95 & 4.06 & .482 & 12 & 82.163 & .000 \\
\hline Technological factors & 95 & 3.91 & .479 & 12 & 79.450 & .000 \\
\hline Socio-Cultural factors & 95 & 3.54 & .353 & 10 & 97.772 & .000 \\
\hline Regulatory factors & 95 & 3.87 & .385 & 10 & 97.852 & .000 \\
\hline Ecological factors & 95 & 3.49 & 1.061 & 30 & 32.115 & .000 \\
\hline Your Creditor’s actions & 95 & 4.33 & .659 & 15 & 63.939 & .000 \\
\hline Market factors (customer behavior) & 95 & 4.19 & 673 & 16 & 60.664 & .000 \\
\hline Labour market dynamics & 95 & 4.14 & .974 & 24 & 41.387 & .000 \\
\hline Trade unions’ activities & 95 & 3.97 & .983 & 25 & 39.332 & .000 \\
\hline $\begin{array}{l}\text { Threat of new entrants into your } \\
\text { corporation's industry }\end{array}$ & 95 & 4.20 & 1.017 & 24 & 40.257 & .000 \\
\hline $\begin{array}{l}\text { Bargaining power of suppliers over your } \\
\text { organization }\end{array}$ & 95 & 3.81 & 1.034 & 27 & 35.903 & .000 \\
\hline $\begin{array}{l}\text { Bargaining power of the public at large } \\
\text { over your organization }\end{array}$ & 95 & 4.29 & .599 & 14 & 69.862 & .000 \\
\hline \multicolumn{7}{|c|}{ (Complexity)Environmental issues that the organizations have had to deal with } \\
\hline Political factors & 95 & 4.13 & .789 & 19 & 50.988 & .000 \\
\hline Economic factors & 95 & 4.18 & .956 & 23 & 42.594 & .000 \\
\hline Technological factors & 95 & 4.09 & .730 & 18 & 54.642 & .000 \\
\hline Socio-Cultural factors & 95 & 4.00 & 1.031 & 26 & 37.799 & .000 \\
\hline Regulatory factors & 95 & 4.39 & .776 & 18 & 55.140 & .000 \\
\hline Ecological factors & 95 & 2.88 & .784 & 27 & 35.873 & .000 \\
\hline Your Creditor's actions & 95 & 3.26 & 1.103 & 34 & 28.828 & .000 \\
\hline
\end{tabular}




\begin{tabular}{|c|c|c|c|c|c|c|}
\hline Statements & $\mathbf{N}$ & Mean & Std. Deviation & CV & $\mathbf{t}$ & Sig. (2-tailed) \\
\hline Market factors (e.g. customer behavior) & 95 & 4.09 & .813 & 20 & 49.084 & .000 \\
\hline Labour market dynamics & 95 & 4.04 & 1.051 & 26 & 37.486 & .000 \\
\hline Trade unions’ activities & 95 & 4.51 & .698 & 15 & 62.945 & .000 \\
\hline $\begin{array}{l}\text { Threat of new entrants into your firm's } \\
\text { industry }\end{array}$ & 95 & 3.07 & 959 & 31 & 31.233 & .000 \\
\hline $\begin{array}{l}\text { Threat of new entrants into your } \\
\text { corporation's industry }\end{array}$ & 95 & 3.31 & 1.158 & 35 & 27.809 & .000 \\
\hline $\begin{array}{l}\text { Bargaining power of suppliers over your } \\
\text { organization }\end{array}$ & 95 & 4.15 & .743 & 18 & 54.383 & .000 \\
\hline $\begin{array}{l}\text { Bargaining power of the public at large } \\
\text { over your organization }\end{array}$ & 95 & 4.03 & 1.026 & 25 & 38.308 & .000 \\
\hline
\end{tabular}

(Complexity) The extent to which developments have in each of the following factors have become more predictable?

\begin{tabular}{lcccccc} 
Political factors & 95 & 4.40 & .721 & 16 & 59.521 & .000 \\
Economic factors & 95 & 2.92 & .794 & 27 & 35.773 & .000 \\
Technological factors & 95 & 3.23 & 1.115 & 35 & 28.244 & .000 \\
Socio-Cultural factors. & 95 & 2.97 & .893 & 30 & 32.411 & .000 \\
Regulatory factors. & 95 & 3.21 & 1.110 & 35 & 28.195 & .000 \\
Ecological factors. & 95 & 4.12 & .810 & 20 & 49.504 & .000 \\
Your Creditor's actions. & 95 & 4.05 & 1.045 & 26 & 37.783 & .000 \\
Market factors (customer behavior). & 95 & 4.51 & .698 & 15 & 62.945 & .000 \\
$\begin{array}{l}\text { Labour market dynamics. } \\
\text { Trade unions' activities. }\end{array}$ & 95 & 3.14 & .996 & 32 & 30.702 & .000 \\
$\begin{array}{l}\text { Threat of new entrants into your } \\
\text { corporation's industry. }\end{array}$ & 95 & 3.33 & 1.171 & 35 & 27.688 & .000 \\
$\begin{array}{l}\text { Bargaining power of suppliers over your } \\
\text { organization. }\end{array}$ & 95 & 4.14 & .724 & 17 & 55.721 & .000 \\
$\begin{array}{l}\text { Bargaining power of the public at large } \\
\text { over your organization. }\end{array}$ & 95 & 4.04 & .999 & 25 & 39.433 & .000 \\
\hline
\end{tabular}

\section{Source: Fieldwork 2015}

As shown in Table 3 the statement "To what extent have the developments trade unions' activities become more predictable" had a mean score of 4.51. The mean score indicated that state corporations in Kenya are to a large extent able to predict developments associated with trade unions. Such a situation is critical in ensuring harmonious labour relations in state corporations. On the other hand, the statement "how many issues does your firm need to deal with related to ecological factors?” had the lowest mean score of 2.88. The mean score indicated that state corporations in Kenya had a moderate extent issues related to ecological environment to deal with set targets that were measurable.

The munificence and dynamism of regulatory factors and trade unions activities had the highest coefficient of variation of 35 percent. Additionally, the dynamism of political factors and threat of new entrants had also a coefficient of variation of 35. This score of coefficient of variation showed that as much as the state corporations operated in an identical external environment context, there was a divergent opinion on how the corporations experienced the external environment.

The dynamism of socio-cultural activities had a coefficient of variation of 10. The score of coefficient of variation showed that there was relative agreement as regards changes brought about by socio cultural activities in state corporations. The t-test for the entire external environment questionnaire items were found to be significant implying that the research instrument was reliable and valid as reinforced by the high Cronbach alpha scores recorded in the reliability test. 
Table 4. The Results of Analysis Done to Determine the Effect of External Environment On Performance of the State Corporations in Kenya

\begin{tabular}{|c|c|c|c|c|c|c|c|}
\hline \multirow[t]{2}{*}{ Model } & \multirow[t]{2}{*}{$\mathbf{R}$} & \multirow[t]{2}{*}{$\mathbf{R}^{2}$} & \multirow[t]{2}{*}{ F-value } & \multirow[t]{2}{*}{ Sig } & \multicolumn{3}{|c|}{ Individual significance } \\
\hline & & & & & munificence & dynamism & complexity \\
\hline $\begin{array}{l}\text { Overall Performance }=\mathrm{F} \text { (External } \\
\text { Environment } \\
\mathrm{P}=1.232 \text { External Environment }\end{array}$ & 0.939 & 0.883 & 696.217 & .000 & \multicolumn{3}{|c|}{ External environment is significant } \\
\hline $\begin{array}{l}\text { Financial }=\mathrm{f}(\text { External } \\
\text { Environment }) \\
\mathrm{FP}=0.433 \text { Dynamism }\end{array}$ & 0.733 & 0.537 & 35.120 & .000 & .334 & .000 & .605 \\
\hline $\begin{array}{l}\text { Customer focus }=\mathrm{f} \text { (External } \\
\text { Environment) } \\
\mathrm{CF}=1.252 \text { Dynamism }\end{array}$ & 0.803 & 0.644 & 54.941 & .000 & .295 & .000 & .155 \\
\hline $\begin{array}{l}\text { Internal Processes = } \mathrm{f}(\text { External } \\
\text { Environment) } \\
\mathrm{IR}=0.587 \text { Dynamism }\end{array}$ & 0.608 & 0.369 & 17.760 & .000 & 677 & .000 & .822 \\
\hline $\begin{array}{l}\text { Learning \& Growth }=f(\text { External } \\
\text { Environment })\end{array}$ & 0.747 & 0.558 & 38.275 & .000 & .474 & .444 & .061 \\
\hline $\begin{array}{l}\text { Social Focus }=\mathrm{f}(\text { External } \\
\text { Environment) } \\
\mathrm{SF}=1.069+0.635 \text { Munificence }\end{array}$ & 0.676 & 0.457 & 25.537 & .000 & .045 & .317 & .612 \\
\hline $\begin{array}{l}\text { Environment }=\mathrm{f}(\text { External } \\
\text { Environment) } \\
\mathrm{E}=1.276 \text { Complexity }-1.093 \\
\text { External Environment (Munificenc }\end{array}$ & 0.695 & 0.483 & plexity) & .000 & .842 & .854 & .013 \\
\hline
\end{tabular}

It was established that external environment explained 88.3 percent $\left(\mathrm{R}^{2}=0.883\right)$ of organizational performance with the remaining 21.7 percent explained by other variables implemented by organizations. The regression model was significant at $\mathrm{F}$ ratio $=696.217$ with a p- value of 0.000 . Since the calculated p-value was less than 0.05 , this indicated that the model was robust enough to explain the relationship between the predictor and dependent variable. The analysis of t-test values showed significant results for strategy implementation

Equation 1 explains the model of external environment and organizational performance of state corporations.

Organizational Performance $=1.232$ External Environment

Additionally, external environment explained between 36.9 percent and 88.3 percent of the six indicators of performance of Kenya state corporations. All the regression models for the six indicators of performance were all significant at 95 percent confidence level.

\section{Discussion}

In order to establish the effect of external environment on overall organizational performance, a composite index of organizational performance comprising of financial performance, customer focus, internal business processes, learning and growth, social equity and environmental integrity variables was computed. The results of analysis established that external environment explained 88.3 percent organizational performance. This results support those of Murgor (2014) who established that external environment has a significant influence on organizational performance in large scale manufacturing firms. Machuki and Aosa (2011) had similar results in companies listed on Nairobi Securities Exchange. Notably, both studies were in different contexts as those of this study. It could be likely that the external environment has a positive influence in major sectors in Kenya. The study established that external environment explained 53.7 percent $\left(\mathrm{R}^{2}=0.537\right)$ of financial performance. The environmental characteristics such as complexity, dynamism and munificence can have an influence on financial performance both indirectly and directly (Machuki, 2011). These results also agree with those of Njuguna et al., (2008) who found a significant positive influence of external environment on financial viability. The study also sought to determine the influence of external environment on customer focus of the Kenyan state corporations. It was established that external environment 
explained 64.4 percent $\left(\mathrm{R}^{2}=0.644\right)$ of customer focus. These findings are in tandem with Pearce and Robinson (2011) postulation that organizations operate in open systems and not as self-contained isolated units but in continuous and inevitable interaction with the large system surrounding them and within which they exist. Perhaps, it appears that this larger system also referred to as the external environment has manifestations that include industry rivalry, bargaining customers, changing customer tastes and preferences that could likely influence an organization's customer focus performance.

The results of analysis done to determine the influence of external environment on internal business processes of the state corporations in Kenya established that external environment explained 36.9 percent $\left(\mathrm{R}^{2}=0.369\right)$ of internal business processes. This finding is in tune with postulations of Gupta (2009) who argued that the external environment can influence internal functioning of organizations. Changes in factors such as labor markets, supplier power, and technology could have an influence on organizational operations. Palmer and Bob (2002) also argue that occurrences in the external environment may impinge on the internal activities of the organization.

Statistical tests were done to determine the influence of external environment on learning and growth of the state corporations in Kenya. It was established that external environment explained 55.8 percent $\left(R^{2}=0.558\right)$ of learning and growth. This results seem to be in congruence with suggestions of Syed-Ikhsan and Rowland (2004) that public organizations should never ignore external environmental manifestations especially politics in implementing knowledge management. The study also sought to determine the influence of external environment on social focus of the state corporations in Kenya. It was established that external environment explained 45.7 percent $\left(R^{2}=0.457\right)$ of social focus. Social equity which is mostly about corporate social responsibility in its simplest form is corporations' broader responsibility towards society (Carroll, 1979). Organizational social performance is influenced by the external environment in which they operate (Alkali, 2012; Pearce \& Robinson, 2007) The results of analysis done to determine the influence of external environment on environmental equity of the Kenyan state corporations established that external environment explained 48.3 percent $\left(R^{2}=0.483\right)$ of environmental equity.

\section{Conclusion}

The main objective of this research was to establish the effect of external environment on performance of Kenya state corporations. The results show that all the hypotheses were supported. It was established that external environment had a significant influence on all the indicators of performance. Further, external environment had a positive effect on the six indicators of organizational performance. Dynamism had a positive effect on three indicators of organizational performance namely financial, customer focus and internal business processes. Munificence, on the other hand, had a positive effect on the social performance of an organization. Finally, complexity had a positive impact on the environmental integrity indicator of organizational performance. It was evident from the findings that the effect of external environment on organizational performance, while conventionally thought to be negative, the research showed otherwise. It is most likely, from analysis of comments made by the research respondents that Kenya state corporations have ensured a proper environmental scanning that has led to a strong SWOT analysis and accurate stakeholders mapping. The stakeholders mapping has most likely led to favorability of relationships hence the positive effect of external environment. External environment ought not to impact organizational performance negatively.

The open system theory's main postulation suggests that as firms conduct their business, they will be influenced by occurrences and changes in their external environment. The results of this study proved this. Perhaps, more significant impact of this study to the theory is the finding that environmental dimensions were found to have a positive rather than negative influence on organizational performance. Scholars and practitioners s should therefore take cognizance that not all external environmental manifestations negatively impact organizational activities. On the contrary others have positive implications.

\section{References}

Alkali, M. (2012). Assessing the influence of external environmental factors on the performance of small business manufacturing enterprises in Bauchi state, Nigeria. Institute of Interdisciplinary Business Research, 4(7), 621-630.

Ansoff, H. I., \& Mc Donnell, E. J. (1990). Implanting Strategic Management (2 ${ }^{\text {nd }}$ Ed.). NY: Prentice Hall.

Ansoff, H. I., \& Sullivan, P. A. (1993). Optimizing profitability in turbulent environments: A formula for strategic 
success. Long Range Planning, 26, 11-23. http://dx.doi.org/10.1016/0024-6301(93)90073-O

Awino, Z. B., \& Mutua, J. M. (2014). Business process outsourcing strategy and performance of Kenyan state corporations. Journal of Emerging Trends in Economics and Management Sciences, 5(7), 37-43.

Awino, Z. B. (2011). Strategic management: An empirical investigation of selected strategy variables on firm performance: a study of supply chain management in large private manufacturing firms in Kenya. Prime Journals, 1(1), 9-18.

Bagire, V., \& Namada, J. (2013). Managerial skills, financial capability and strategic planning in organizations. American Journal of Industrial and Business Management, 3, 480-487. http://dx.doi.org/10.4236/ajibm.2013.35055

Bourgeois, L. J. (1980). Strategy and environment: A conceptual integration. Academy of Management Review, 5(1), 25-39.

Carroll, A. (1979). A three-dimensional conceptual model of corporate performance. Academy of Management Review, 4(4), 497-505.

Castrogiovanni, G. J. (1991). Environmental munificence: A theoretical assessment. Academy of Management Review, 16(3), 542-565.

Chakravathy, B. S. (1986). Measuring strategic performance. Strategic Management Journal, 7, 437-458. http://dx.doi.org/10.1002/smj.4250070505

Cooper, D. R., \& Schindler, P. S. (2006). Business Research Methods (9th Ed.). NY: McGraw-Hill.

Dess, G. G., \& Beard, D. W. (1984). Dimensions of organizational task environments. Administrative Science Quarterly, 29(1), 52-73. http://dx.doi.org/10.2307/2393080

Dimaggio, P., \& Powell, W. (1991). The iron cage revisited: Institutional isomorphism and collection rationality in organizational fields. American Sociological Review, 48, 147-160. http://dx.doi.org/10.2307/2095101

Dreyer, B., \& Gronhaug, K. (2004). Uncertainty, flexibility, and sustained competitive advantage. Journal of Business Research, 57, 484-494. http://dx.doi.org/10.1016/S0148-2963(02)00315-6

Duncan, R. G. (1972a). Characteristics of organizational environments and perceived environmental uncertainty. Administrative Science Quarterly, 17(2), 313-327. http://dx.doi.org/10.2307/2392145

Edmondson, M., \& Watkins, M. (2003). A dynamic model of top management team effectiveness. The Leadership Quarterly, 14, 297-325. http://dx.doi.org/10.1016/S1048-9843(03)00021-3

Government of Kenya. (2013). Report of the presidential taskforce on parastatal reforms. Retrieved from www.apsea.or.ke/.../76-report-of-presidential-taskforce-on-parastatal-reforms

Gupta, A. (2009). Organization external environment. Retrieved from http://www.practical-management.com

Gupta, A. K., \& Govindarajan, V. (1984). Business unit strategy, managerial characteristics, and business unit effectiveness at strategy implementation. Academy of Management Journal, 27(1), 25-41.

Hitt, M. A., Ireland, R. D., Sirmon, D. G., \& Trahms, C. A. (2011). Strategic entrepreneurship: creating value for individuals, organizations, and society. The academy of management perspectives, 25(2), 57-76. http://dx.doi.org/10.5465/AMP.2011.61020802

IDRC. (1999). Enhancing organizational performance. Ottawa: IDRC.

Kacperczyk, A. (2009). With greater power comes greater responsibility? Takeover protection and corporate attention to stakeholders. Strategic Management Journal, 30(3), 261-285. http://dx.doi.org/10.1002/smj.733

Kaplan, R., \& Norton, D. (2008). Execution premium: Linking strategy to operations for competitive advantage. Harvard Business School Press.

Kaplan, R. S., \& Norton, D. P. (2008). Mastering the management system. Harvard Business Review, 86(1), 29-48.

Kaplan, R., \& Norton, D. (1992). The balanced scorecard: The measures that drive performance. Harvard Business Review Jan-Feb, 71-79.

Khandwalla, P. (1977). The Design of organizations. New York. Harcourt: Brace, Jovanovich.

Kinuu, D. (2014). Top management team psychological characteristics, institutional environment, team processes and performance of companies listed in Nairobi securities exchange. University of Nairobi, Unpublished Ph.D. 
Thesis.

Kobia, M., \& Mohammed, N. (2006). The Kenyan experience with performance contracting, African association for public administration and management. 28th AAPAM Annual Round Table Conference, Arusha, Tanzania.

Lehner, J. (2004). Strategy implementation tactics as response to organizational, strategic, and environmental imperatives. Management Review, 15(4), 460-480.

Machuki, V. N., \& Aosa, E. (2011). The influence of external environment on the performance of publicly quoted companies in Kenya. Business Administration and Management Journal, 1(7), 205-218.

Machuki, V. N., Aosa, E., \& Letting, N. K. (2012). Firm-level institutions and performance of publicly quoted companies in Kenya. International Journal of Humanities and Social Science, 2(21), 298- 312.

March, J. G., \& Sutton, R. I. (1997). Organizational performance as a dependent Variable. Journal of Organization Science, 8(6), 698-706. http://dx.doi.org/10.1287/orsc.8.6.698

McMahon, D., \& Carr, J. C. (1999). The contributions of Chester Barnard to strategic management theory. Journal of Management History, 5, 228-240. http://dx.doi.org/10.1108/13552529910282222

Messah, O. B., \& Kariuki, F. K. (2011). Factors Affecting implementation of performance contract initiative at municipal council of Maua-Kenya. Journal of Finance and Accounting, 2, 22- 46.

Miller, K. D. (1993). Industry and country effects on managers' perceptions of environmental uncertainties. Journal of International Business Studies, 24(4), 693-714. http://dx.doi.org/10.1057/palgrave.jibs.8490251

Mkalama, R. N. (2014). Top management demographics, strategic decision making, and macro-environment and performance of Kenyan state owned corporations. University of Nairobi, Unpublished Ph.D. Thesis.

Murgor, P. K. (2014). External environment, firm capabilities, strategic responses and performance of large scale manufacturing firms in Kenya. University of Nairobi, Unpublished Ph.D. Thesis.

Njoroge, J. K., Machuki, V. N., Ongeti, W. J., \& Kinuu D. (2015). The Effect of strategy implementation on performance of Kenya state corporations. Prime Journals, 5(9), 1913-1922

Njuguna, K., Munyoki, M., \& Kibera, F. (2008). Influence of external organizational environment on performance of community-based HIV and aids organizations in Nairobi county, Kenya. European Scientific Journal, 10(28), $1857-1881$

Ombaka, B., Muindi F., \& Machuki, V. (2015). Effectiveness of the balanced scorecard in implementation of corporate strategy - A case study of a Kenyan insurance companies. Prime Journal of Business Administration and Management, 5(11), 1941-1948,

Ongeti, W. J. (2014). Organizational Resources, Corporate Governance and Performance of Kenyan State Owned Corporations. University of Nairobi, Unpublished Ph.D. Thesis.

Osborn, N. R., \& Hunt, G. J. (1974). Environment and organizational effectiveness. Administrative Science Quarterly Review, 19(2), 231-246. http://dx.doi.org/10.2307/2393892

Osborne, J. W., Christensen, W. R., \& Gunter, J. (2001). Educational psychology from a statistician’s perspective: A review of the power and goodness of educational psychology research. (Paper presented at the national meeting of the American Education Research Association (AERA), Seattle: WA.

Palmer, A., \& Bob, H. (2002). The business environment. London: McGraw-Hill Co.

Pearce, A. J., \& Robinson, B. R. (2007). Strategic management formulation, implementation and control (10th ed). Boston: Irwin McGraw-Hill.

Pearce, A. J., \& Robinson, B. R. (2011). Strategic management formulation implementation and control (12th ed). Boston: Irwin McGraw-Hill

Scott, W. R. (2004). Institutional Theory. Encyclopedia of Social Theory. George Ritzer, Thousand Oaks, CA: Sage.

Scott, W. R. (2008). Institutions and organizations ideas and interests. Los Angeles: Sage Publications, Inc.

Syed-Ikhsan, S. O. S., \& Rowland, F. (2004). Knowledge management in a public organization: A study on relationship between organizational elements and the performance of knowledge transfer. Journal of Knowledge Management, 8(2), 95-111. http://dx.doi.org/10.1108/13673270410529145

Tacheva, S. (2007). Top management team internationalization: Construct development and empirical test. 
Unpublished Doctoral Dissertation, University of St. Gallen Tan and Litschert.

Venkatraman, N., \& J. E. Prescott (1990). Environment-Strategy Coalignment: An empirical test of its performance implications. Strategic Management Journal, 11, 1-23. http://dx.doi.org/10.1002/smj.4250110102

Venkatraman, N., \& Ramunajam, V. (1987). Measurement of business economic performance: an examination of method convergence. Journal of Management, 13, 109-122. http://dx.doi.org/10.1177/014920638701300109

Welch, J., \& Welch, S. (2005). Winning. Harper Business, New York. 